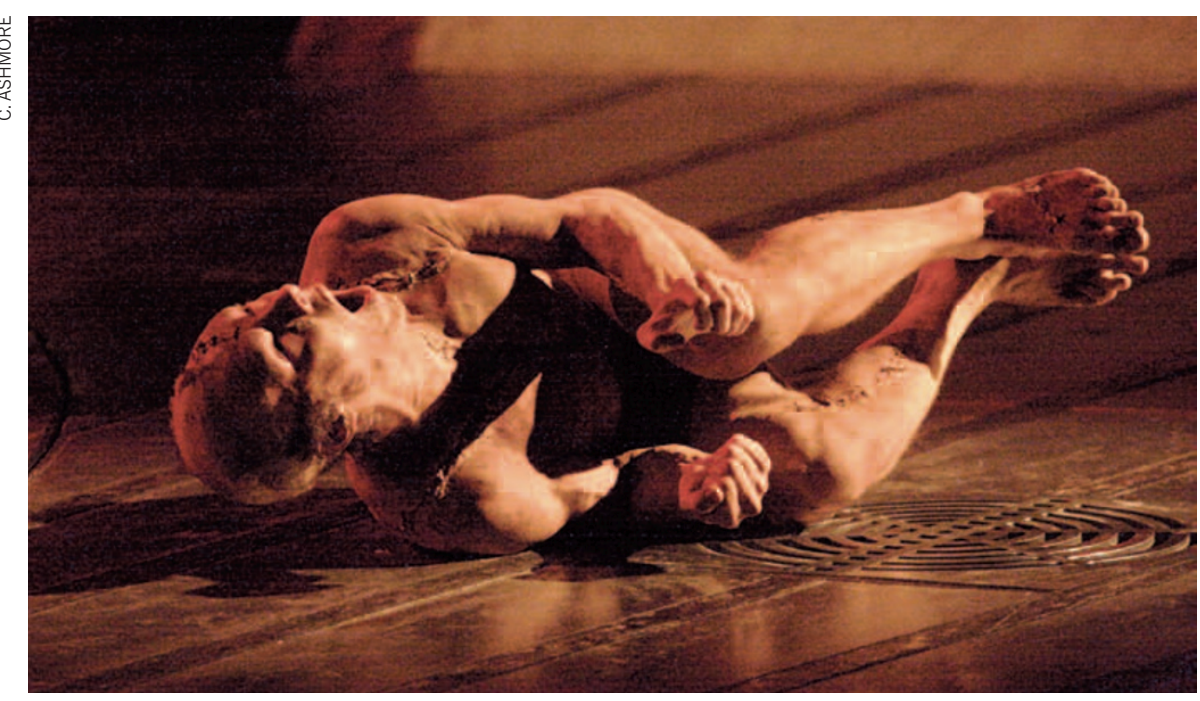

Benedict Cumberbatch plays Frankenstein's creation in a London adaptation directed by Danny Boyle.

THEATRE

\title{
A monstrous tale
}

\section{A new staging of Frankenstein plays up the monster but draws no morals about science, finds Philip Ball.}

$\mathrm{M}$ ary Shelley's Frankenstein has been adapted and reinterpreted innumerable times since it was first published, anonymously, in 1818 . Victor Frankenstein has become the archetypal mad scientist, unleashing powers he cannot control. The 'Franken-' label is attached to every new technology that seems to intervene in life, from genetic modification of crops to Craig Venter's synthetic microbe.

The latest staging of the tale is Nick Dear's adaptation for the National Theatre in London, directed by Danny Boyle, famous for films including Trainspotting (1996) and Slumdog Millionaire (2008). The production is spectacular, and intelligent choices were made in the structure of the play (if not always in the dialogue). By placing the creature at the heart of the performance (played by Jonny Lee Miller, on the night I saw it), Dear has wisely emphasized the human message of the story rather than attempting any ill-advised jibe at the hubris of contemporary science.

The first adaptations for the stage began as early as the 1820s. These transformed Frankenstein's creature into the now-familiar mute, shambling brute, at that time based on the stock theatrical character of the Wild Man. This personification continued in the first film adaptation in 1910, simply called Frankenstein. As well as the iconic screen version by James Whale in 1931 with Boris Karloff's creature, there have been countless other renditions, sequels, parodies (Mel Brooks's 1974 The Rocky Horror Picture Show in 1975) and postmodern interpretations (Brian Aldiss's Frankenstein Unbound; Jonathan Cape, 1973).

Some might lament how the original novel has been distorted and vulgarized in that process. British literary critic Chris Baldick has a wiser perspective. He argues in his book In Frankenstein's Shadow (Oxford University Press, 1987) that in interpreting a myth, we must consider all its versions: "That series of adaptations, allusions, accretions, analogues, parodies, and plain misreadings which follows upon Mary Shelley's novel is not just a supplementary component of the myth; it is myth." After all, there is no definitive version of Shelley's story. She made small but significant changes in the third edition in 1831, emphasizing the Faustian themes of presumption and retribution on which the early stage versions insisted.

Critics still dispute what Shelley's message was meant to be. Far from offering a simplistic critique of scientific hubris, the story might instead echo Shelley's troubled family life. Her mother, the feminist and political radical

\section{$\checkmark$ NATURE.COM}

For a review of Philip Ball's Unnatural: go.nature.com/jgmb15
Mary Wollstonecraft, died from complications after Mary's birth, and her father, William Godwin, all but disowned her after she eloped to Europe with the poet Percy Shelley in 1814. She lost her first child, named Clara, that year, subsequently describing a dream in which the girl was reanimated. There is ample reason to believe Percy Shelley's statement that the central moral of Frankenstein is: "Treat a person ill, and he will become wicked."

If so, Dear's adaptation has returned to the essence of the tale: it focuses on the plight of the creature, whose lone and awkward 'birth' begins the play. We see how this mumbling wretch, spurned as a hideous thing by Victor, is reviled by society until finding refuge with the blind peasant De Lacey. The kindly old man teaches the creature how to speak and read using Milton's Paradise Lost, the story of Satan's Promethean challenge to heaven.

Eventually, De Lacey's son and daughter-inlaw return from the fields and drive out the creature in horror, whereupon he burns them in their cottage. These scenes are the moral core of Shelley's novel, and in placing them so early, Dear signals that this is very much the monster's show. In fact, perhaps too much. For while the creature is the most fully realized, most sympathetic and inventive incarnation I have seen, Victor Frankenstein is left with little to do but recoil from him and neglect all his other duties: martial, filial and moral. It is clear from the outset who is the real monster.

Throughout the run of this production, the two lead actors - Benedict Cumberbatch and Miller - alternate the roles of Victor and his creature. This Döppelganger theme is not a new one. In the 1927 British stage adaptation by Peggy Webling that formed the basis of Whale's movie, the creature appeared dressed like the scientist, who foreshadows the later elision of creator and creature by saying: "I call him by my own name - he is Frankenstein."

The scientific elements of the tale are skated over. Mary Shelley provided just enough hints for the informed reader to make the connection with Italian physician Luigi Galvani's then-recent work on electrophysiology. Dear has Frankenstein mention galvanism and electrochemistry, but that is as far as it goes. There is no serious attempt to make the play a comment on the "Promethean ambitions" of modern science, as Pope John Paul II called them in 2002. This is a relief, because the trope of a solitary experimenter exceeding the bounds of God and nature is no longer the relevant vehicle for a critique.

Whether Dear adds anything new to the legend - as Whale and arguably even Brooks did -is debatable. But it is good to be reminded that the novel may be read not so much as a Gothic tale of monstrosity and presumption, but as a comment on the consequences of how we treat one another.

Philip Ball is author of Unnatural: The Heretical Idea of Making People. e-mail:p.ball@btinternet.com 